\title{
Cover crop residue diversity enhances microbial activity and biomass with additive effects on microbial structure
}

Article

Accepted Version

Shu, X., Zou, Y., Shaw, L. J., Todman, L., Tibbett, M. and Sizmur, T. ORCID: https://orcid.org/0000-0001-9835-7195 (2021) Cover crop residue diversity enhances microbial activity and biomass with additive effects on microbial structure. Soil Research, 60 (4). pp. 349-359. ISSN 1838-675X doi: https://doi.org/10.1071/SR21105 Available at https://centaur.reading.ac.uk/100763/

It is advisable to refer to the publisher's version if you intend to cite from the work. See Guidance on citing.

To link to this article DOI: http://dx.doi.org/10.1071/SR21105

Publisher: CSIRO Publishing

All outputs in CentAUR are protected by Intellectual Property Rights law, including copyright law. Copyright and IPR is retained by the creators or other copyright holders. Terms and conditions for use of this material are defined in the End User Agreement. 


\section{CentAUR}

Central Archive at the University of Reading

Reading's research outputs online 


\title{
Cover crop residue diversity enhances microbial activity and biomass with
}

\section{additive effects on microbial structure}

\author{
Xin Shu ${ }^{a}$, Yiran Zoua, Liz J. Shaw ${ }^{a}$, Lindsay Todman ${ }^{b}$, Mark Tibbett ${ }^{b}$, and Tom Sizmur ${ }^{a}$ *

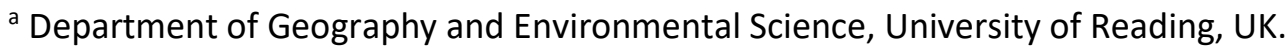 \\ ${ }^{\mathrm{b} S}$ School of Agriculture, Policy and Development, University of Reading, UK. \\ * Corresponding author - t.sizmur@reading.ac.uk
}

Tel: $+44(0) 1183788913$

\begin{abstract}
Cover crops have been widely used in agroecosystems to improve soil fertility and environmental sustainability. The decomposition of cover crop residues can have further effects on belowground communities and their activity, which is important for a series of soil functions (e.g., nutrient cycling and organic matter decomposition). We tested the effect of plant residues from a range of cover crop species on soil microbial activity and community assemblage. We predicted that cover crop residues would alter the soil microbial community and that a greater diversity of residues would enhance microbial decomposition. In an incubation study, we assessed the effect of crop residue diversity on microbial activity (soil respiration) and its consequent effects on microbial community composition (PLFA). We used either a biodiverse mixture of four cover crop residues (buckwheat, clover, sunflower, and radish) or an equal mass of the residues of each of the individual species. Cover crop residue incorporation significantly $(P<0.001)$ increased soil respiration during 84 days' incubation and this universal response caused a significant change in microbial community composition
\end{abstract}


by increasing the proportion of fungi and Gram-positive bacteria at the cost of decreasing Gram-negative bacteria. The diverse mixture of cover crop residues had a significantly $(P<$ 0.05) greater soil respiration rate, by $57.61 \mu \mathrm{g} \mathrm{g} \mathrm{g}^{-1} \mathrm{~h}^{-1}$, than the average of the four individual residues, but did not have a significantly different soil microbial biomass or microbial community structure. This finding could be attributed to a greater diversity of organic resources increasing the number biochemical niches, and hence activating dormant microbial communities to increase microbial activity without affecting microbial biomass or community composition. Greater respiration from similar microbial biomasses suggests that microbial activity might be more efficient after a more diverse substrate input. This study confirms the positive impact of cover crop residues on soil microbial biomass and activity and highlights that mixtures of cover crop residues may deliver enhanced soil functions beyond the sum of individual cover crop residues.

Key words: residue diversity, soil function, respiration, mixture, litter 


\section{Introduction}

Integrating cover crops, non-cash crops grown primarily for the purpose of protecting or improving soil health between cash-crops in an arable crop rotation, is a popular tool to increase the sustainability of agricultural land management (Abdalla et al. 2019). The use of cover crops has recorded benefits, such as increasing soil carbon storage, controlling soil erosion, enhancing agricultural productivity, reducing herbicide usage, managing diseases, increasing root biomass, and increasing the soil microbial biomass (Zheng et al. 2018; Daryanto et al. 2018; Abdalla et al. 2019; Kim et al. 2020). Since each individual species may excel at providing one or a few soil functions, a multi-species cover crop mixture is often used to maximise agroecological benefits (Daryanto et al. 2018).

After the termination of cover crops, the decomposition of their residues can have further effects on belowground communities since the organic matter that is incorporated into soil is a significant driver of changes to the soil food web and microbial growth (Bonanomi et al. 2017). The biological degradation of plant residues is mainly carried out by bacteria and fungi (Manzoni et al. 2008). How quickly and efficiently microorganisms can degrade plant residues and assimilate the substrates into their biomass is closely linked to microbial stoichiometric requirements and the biochemical composition of plant residues (Sinsabaugh et al. 2013). In particular, the $\mathrm{C} / \mathrm{N}$ ratio and the ratio of lignin to total $\mathrm{N}$ are the most important direct regulators of litter decomposition (Zhang et al. 2008). In N rich residues, decomposition can proceed without decomposers needing to scavenge exogenous $\mathrm{N}$ pools to meet stoichiometric requirements (Manzoni et al. 2008; Talbot and Treseder 2012; Ye et al. 2018). In contrast, $\mathrm{N}$ limitation could be a barrier for microorganisms to decompose residues with higher C/N ratio (Manzoni et al. 2008; Talbot and Treseder 2012; Ye et al. 2018). Different 
microbial groups may differ with respect to their preference in decomposing $C$ substrates of distinct complexity and availability. For example, bacteria may be more effective competitors for the utilization of low molecular weight labile $C$ substrates, while fungi may more easily mineralise larger and more complex biopolymers (Meidute et al. 2008).

Due to differences in resource quality between plant species, the decomposition of residue mixtures can exhibit non-additive synergistic (mixture is decomposed faster than the predicted from single species), non-additive antagonistic (mixture is decomposed slower than the predicted) or additive effects (decomposition rate of mixture equals prediction) (Redin et al. 2014). Gartner and Cardon (2004) reviewed 30 studies covering a wide range of ecosystems and found that about $67 \%$ of studies demonstrated a non-additive synergistic effect on plant residue decomposition of a mixture of plants, compared with what would have been predicted from single species.

There are three possible explanations for non-additive effects of plant residue mixtures on soil microbial functions: (i) nutrient transfer between plant residues, since nutrients released from rapidly decaying and higher quality plant residues (low $\mathrm{C} / \mathrm{N}$ ) can stimulate decay of lower quality plant residues (high C/N) (Gartner and Cardon 2004) and microbial N translocation between plant residues (Schimel and Hättenschwiler 2007) and redistribution of $\mathrm{N}$ within fungal hyphal network (Gessner et al. 2010) could mediate the decomposition of plant residue mixtures restricted by $\mathrm{N}$-limitation and reduce the need to synthesise lignin-modifying enzymes (Chen et al. 2018)mixing chemically contrasting plants provides a greater number of niches for microorganisms to exploit which allows functionally dissimilar microbial communities to coexist, and thus result in a greater microbial diversity and more efficient nutrient cycling (Chapman and Newman 2010; Eisenhauer et al. 2013), or (iii) inhibitory 
secondary compounds such as phenolics released from one plant residue can decrease decay rates of adjacent plant residues, and results in an overall reduced decomposition rate (Gartner and Cardon 2004). The factors responsible for whether a particular plant residue mixture induces an additive or non-additive (antagonistic or synergetic) effect are not all known, but could be related to, the chemical composition of the plant species selected, the mixing ratio, the number of species in the mix, and the soil function measured (Wu et al. 2013; Redin et al. 2014).

We established a microcosm experiment to uncover the impacts of cover crop residue mixtures comprising residues from plants from different plant families and with contrasting functional traits on a soil key function (respiration) and the microbial community biomass and composition. We chose the residues of four individual cover crops, i.e., buckwheat, clover, radish sunflower, and a quaternary mixture which contains $25 \%$ residues from each individual by mass. These four plants are widely used as cover crops in agroecosystems because of their functional traits, i.e. buckwheat improves phosphorus efficiency, clover supplies $N$ to subsequent cash crop, radish alleviates soil compaction, and sunflower provides considerable aboveground biomass to feed soil microorganisms after incorporation (Chapagain et al. 2020). Therefore, the mixture of these four species may deliver multiple benefits. Moreover, these four plants are from different plant families (Polygonaceae, Fabaceae, Brassicaceae, and Asteraceae) and thus will synthesize family-specific primary and secondary metabolites which may have distinct impact on soil microbial communities and activities (Wink 2008). The motivation for this study was to determine if combining the residues of multiple contrasting plant in a realistic mixture could alter respiration and soil microbial community structure to a greater extent than expected, based on observing the effect of the individual residues. We 
hypothesized that 1 ) applying cover crop residues would increase soil respiration and microbial biomass due to the increased nutrient inputs; 2) soil microbial community structure would be shifted by cover crop residues in a plant species-specific way, and 3) the quaternary mixture which supplies a diverse array of resources may satisfy disparate microbial communities, facilitate microbial respiration, and thus exhibit a synergetic interaction, compared to the average of the four individual residue treatments.

\section{Materials and methods}

\subsection{Soil samples and plant residues}

Soil was sampled from an arable field on the University of Reading's research farm at Sonning, Reading, UK (51.481152, -0.902188) in November 2018 after harvesting Spring barley (Hordeum vulgare). The soil is classified as silty loam Luvisol (World Reference Base classification) with $\mathrm{pH}\left(\mathrm{H}_{2} \mathrm{O}\right) 6.3,22.32 \mathrm{~g} \mathrm{C} \mathrm{kg}^{-1}, 2.24 \mathrm{~g} \mathrm{~N} \mathrm{~kg}^{-1}, 0.90 \mathrm{mg} \mathrm{NH}_{4}{ }^{+}-\mathrm{N} \mathrm{kg}^{-1}, 2.75 \mathrm{mg}$ $\mathrm{NO}_{3}{ }^{-}-\mathrm{N} \mathrm{kg}^{-1}$. Five surface soil samples $(0-20 \mathrm{~cm}$ depth) were randomly sampled and mixed thoroughly to create one homogenous sample approximately $20 \mathrm{~kg}$ in weight.

Four cover crops, buckwheat (Fagopyrum esculentum), berseem clover (Trifolium alexandrinum), sunflower (Helianthus annuus), and oil radish (Raphanus raphanistrum), were grown between August and October 2018 in an area adjacent to where the soil was collected. Aboveground residues were harvested during the vegetative growth stage, dried at $70{ }^{\circ} \mathrm{C}$ and milled to pass through $0.05 \mathrm{~mm}$ mesh. The elemental composition of each cover crop residue, and the quaternary mixture (which consisted of $25 \%$ by mass of each of the four cover crops), is provided in Table 1 and S1. 
Table 1 The nutrient contents of the cover crop residues used in experiments and the rate of $\mathrm{C}$ and $\mathrm{N}$ added to soils in the five treatments receiving cover crop residues.

\begin{tabular}{|c|c|c|c|c|c|}
\hline Element & Buckwheat & Clover & Radish & Sunflower & Mixture \\
\hline $\mathrm{Ca}\left(\mathrm{mg} \mathrm{kg}^{-1}\right)$ & 29600 & 21100 & 33400 & 35300 & 30200 \\
\hline $\mathrm{K}\left(\mathrm{mg} \mathrm{kg}^{-1}\right)$ & 21600 & 19800 & 35300 & 30700 & 26700 \\
\hline $\mathrm{Mg}\left(\mathrm{mg} \mathrm{kg}^{-1}\right)$ & 3830 & 2230 & 2080 & 7010 & 3720 \\
\hline$P\left(\mathrm{mg} \mathrm{kg}^{-1}\right)$ & 4610 & 3860 & 5200 & 5310 & 4920 \\
\hline $\mathrm{S}\left(\mathrm{mg} \mathrm{kg}^{-1}\right)$ & 2420 & 2680 & 3790 & 4810 & 3780 \\
\hline $\mathrm{N}(\%)$ & 1.98 & 4.05 & 3.38 & 4.72 & 3.53 \\
\hline C (\%) & 38.8 & 42.1 & 38.9 & 39.4 & 39.8 \\
\hline $\mathrm{C} / \mathrm{N}$ ratio & 19.6 & 10.4 & 11.5 & 8.3 & 12.5 \\
\hline Added C (mg C g ${ }^{-1}$ soil) & 9.46 & 10.27 & 9.50 & 9.62 & 9.71 \\
\hline Added $\mathrm{N}$ (mg N g-1 soil) & 0.24 & 0.48 & 0.40 & 0.56 & 0.42 \\
\hline
\end{tabular}

\subsection{Soil incubation and measurement of respiration}

Soil was sieved to pass $4 \mathrm{~mm}$ mesh and then pre-incubated for 7 days at $26^{\circ} \mathrm{C}$ with a soil water content of $60 \%$ of the water holding capacity $\left(0.22 \mathrm{~g}\right.$ water $\mathrm{g}^{-1}$ soil). The treatments consisted of individual residue of buckwheat, clover, radish and sunflower, a quaternary mixture, and a control without any amendment with cover crop residues. For each treatment receiving plant residues, four replicate units were established by mixing $250 \mathrm{~g}$ of fresh soil (equivalent to $204.92 \mathrm{~g}$ dry soil) thoroughly with $5 \mathrm{~g}$ dry plant residues stored in a plastic bag. The amount of added $\mathrm{C}$ and $\mathrm{N}$ for each treatment was described in Table 1. 
For each treatment and replicate, one aliquot of $200 \mathrm{~g}$ mixture of soil and plant was taken from the plastic bag, transferred, and loosely packed to a bulk density of $1 \mathrm{~g} \mathrm{~cm}^{-3}$ in a pot (200 $\mathrm{ml})$. The pots were stored in a gas-tight plastic container $(940 \mathrm{ml})$ with a headspace gas sampling port covered with a parafilm when not in sampling, and incubated at $26^{\circ} \mathrm{C}$. Soil respiration was measured as $\mathrm{CO}_{2}$ flux following (Adekanmbi et al. 2020) at 0, 1, 2, 3, 6, 7, 8, 9, $10,13,14,30,35,42,49,63,70,77,84$ days after the addition of cover crop residues. Briefly, a parafilm was replaced with a Suba Seal ${ }^{\circledR}$ septa and $16 \mathrm{ml}$ of headspace gas was collected by syringe after closure of the chamber for one hour, and stored in a pre-evacuated Labco exetainers $^{\circledR}$ vials $(12 \mathrm{ml})$. Gas from jars without soils was collected at the beginning of incubation to calibrate the background atmospheric $\mathrm{CO}_{2}$ concentration. Gas samples were analysed by gas chromatography with a thermal conductivity detector (Agilent GC 6890, UK). The universal gas law was used to determine the amount of $\mathrm{CO}_{2}$ as described by (Adekanmbi et al. 2020).

For each treatment and replicate, another three $5 \mathrm{~g}$ aliquots of the soils mixed with plant residues were stored in $30 \mathrm{ml}$ polypropylene tubes and incubated at the same temperature as the samples for gas analysis for the analysis of PLFA at 1, 35 and 84 days after the addition of cover crop residues. Water was added to soils for gas and PLFA analysis regularly to compensate water loss.

\subsection{PLFA}

Soils were frozen on the day of sampling and then freeze-dried for downstream analysis of PLFA. PLFA was extracted following the method described by Sizmur et al., (2011). Briefly, $2 \mathrm{~g}$ of freeze-dried soil was extracted with $7.8 \mathrm{ml}$ of one-phase extractant containing chloroform: methanol: citrate buffer (1:2:0.8 v/v/v). The extracted phospholipids were methanolized as 
fatty-acid methyl esters and then analysed using gas chromatography (Agilent Technologies 6890N, UK) (Frostegård et al. 1993). Peaks were identified using a bacterial fatty acid methyl esters (BAME) mix (Sigma Aldrich, UK) and quantified using a 37-component fatty acid methyl esters (FAME) mix (Sigma Aldrich, UK). The biomass of each group of microorganisms was determined using the combined mass of fatty acids to which the group is attributed in Table S2.

\subsection{Data analysis}

All the statistics were conducted in R (version 3.5.2) (R Core Team 2018) except for analysis of similarity (ANOSIM). We fit two separate linear mixed-effects model (LMM) using REML (restricted maximum likelihood) under the package "nmle" (Pinheiro et al. 2018). Homogeneous residue plots indicated that LMM fits the data well. One LMM identifies the fixed effect from different treatment and time, and random effect from sample replicates on soil respiration rate and PLFA biomass. Another LMM identifies the fixed effect from the cover crop quaternary mixture and the average of the four individuals, and random effect from sample replicates on respiration rate and PLFA biomass. A Pearson correlation matrix was built to explore the relationship between respiration and microbial biomass.

Non-metric multidimensional scaling (NMDS) on Bray-Curtis distance of microbial communities (Hellinger transformed PLFA data) was performed using the "vegan" package (Oksanen et al. 2019) to distinguish soil microbial community structure influenced by cover crop residues. Bray-Curtis distance similarity matrices were calculated and used for a twoway analysis of similarity (ANOSIM) using Primer-e Version 7 (New Zealand) to test the significance of treatment and time on the soil microbial community structure. 


\section{Results}

\subsection{Effects of applying cover crop residues on soil respiration and microbial biomass}

The addition of cover crop residues significantly $(P<0.001)$ increased soil respiration rate over 84 days, compared to the unamended control (Figure 1 and Table S3). Overall, the addition of buckwheat, clover, sunflower, radish and a mixture containing $25 \%(\mathrm{w} / \mathrm{w})$ of all four residues, resulted in an increase in soil respiration rate by $337,340,372,373$, and $359 \mu \mathrm{g} C$ $\mathrm{g}^{-1} \mathrm{~h}^{-1}$, compared to the unamended control soil respiration rate of $29 \mu \mathrm{g} \mathrm{g} \mathrm{g}^{-1} \mathrm{~h}^{-1}$ (Table S3). The response of soil respiration to cover crop residue addition was rapid but was followed by a steep decline in respiration rate over 84 days (Figure 1 ). The respiration rate in the soil which received sunflower residue was significantly $(P<0.05)$ higher than buckwheat and clover which had the lowest respiration rate (Table S4). 

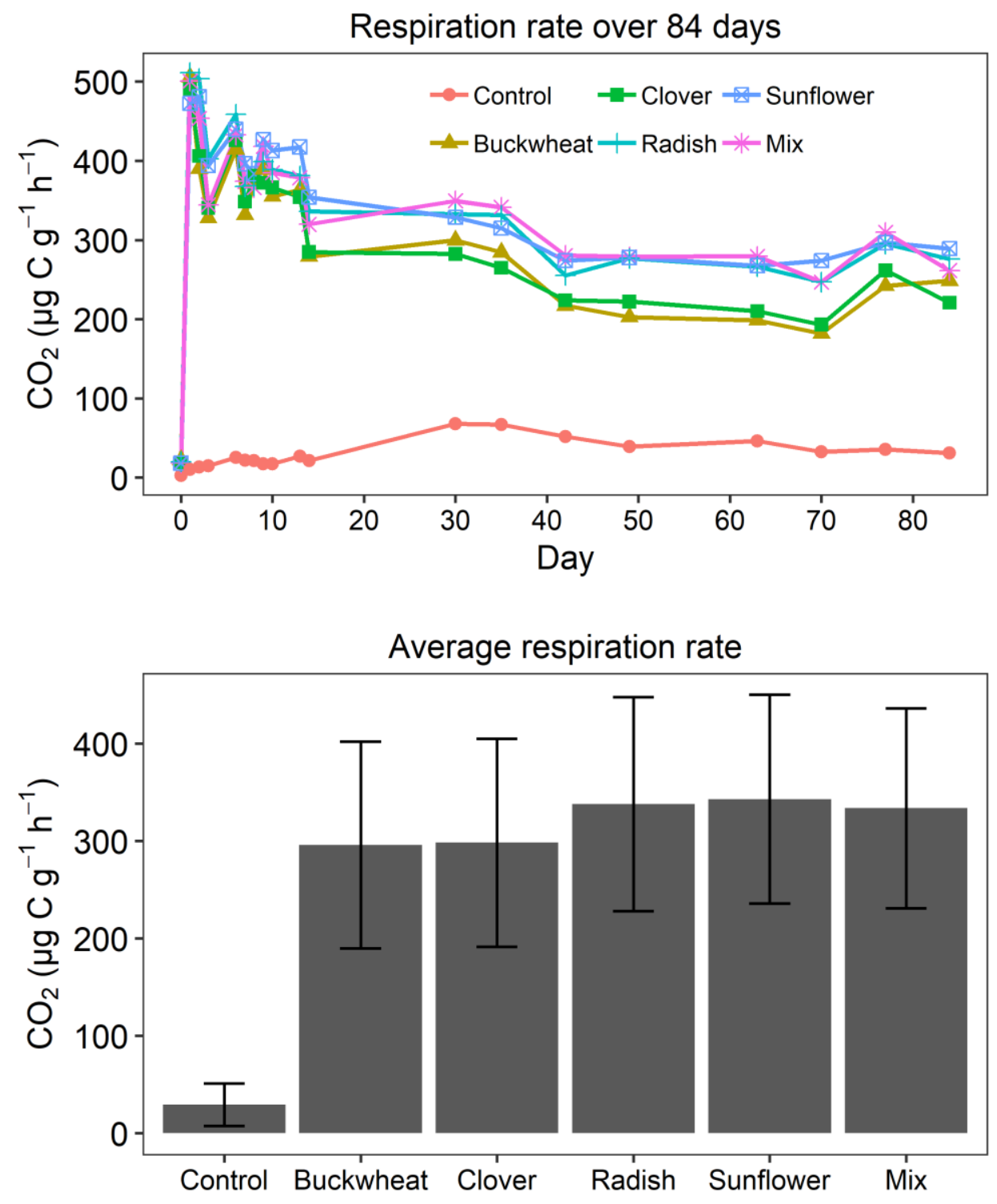

Figure 1 Soil respiration rate in different treatments over 84 days (upper pane), and the average respiration rate (lower pane). Mix is the quaternary mixture of buckwheat, clover, radish and sunflower containing $25 \%(w / w)$ of all four residues. Control is soil without the addition of plant residues. $n=4$

Cover crop residues also significantly $(P<0.001)$ increased the growth of microorganisms, as revealed by a greater total PLFA biomass, compared to the unamended control treatment (Figure 2 and Table S3). Overall, the addition of cover crop residues resulted in an increase of total PLFA biomass by $46,64,53,66$, and $59 \mu \mathrm{g} \mathrm{C} \mathrm{g}{ }^{-1}$ soil for buckwheat, clover, sunflower radish and the quaternary mixture, compared to the unamended control of which total PLFA 
was $18 \mu \mathrm{g} \mathrm{C} \mathrm{g}^{-1}$ (Table S3). There were no significant differences in total PLFA biomass between the treatments receiving different cover crop residues (Table S4).

The biomass of fungi $(P<0.001)$, Gram-positive bacteria $(P<0.001)$, Gram-negative bacteria $(P<0.001)$, cyanobacteria $(P<0.05)$ and a group of fatty acids that cannot be attributed to an individual microbial group $(P<0.05)$ were significantly increased by the addition of cover crop residues (Table S3 and Figure 2). Arbuscular mycorrhizal fungi and actinobacteria only occupy $0.5-3 \%$ and $1.5-6.9 \%$ of the total microbial biomass, respectively (Figure 2 ) and did not significantly respond to any cover crop residue addition (Table S3). The abundance of fatty acids attributed to protozoa (20:3 $\omega 6 \mathrm{c}$ and 20:4 $\omega 6 \mathrm{c})$ and a general fatty acid biomarker for eukaryotes $(18: 3 \omega 6)$ were significantly $(P<0.05)$ increased by the addition of buckwheat, clover and the quaternary mixture of residues (Figure 2 and Table S3). Except for radish, the application of cover crop residues significantly $(P<0.05)$ increased the abundance of a general fatty acid biomarker for eukaryote.

The ratio of fungi to bacteria in the unamended soil is 0.35 . On average, the ratio of fungi to bacteria was significantly $(P<0.001)$ increased by $0.35,0.46,0.54,0.30$ and 0.44 following the addition of buckwheat, clover, sunflower, radish and the quaternary mixture of residues (Table S3 and Figure S1).

Soil respiration rate was significantly correlated to total PLFA biomass ( $r=0.89, P<0.001)$, fungi $(r=0.85, P<0.001)$, Gram-positive bacteria $(r=0.89, P<0.001)$, Gram-negative bacteria $(r=0.35, P<0.001)$, Cyanobacteria $(r=0.51, P<0.001)$, AM fungi $(r=0.27, P<0.05)$, and Eukaryote $(r=0.33, P<0.01)$ (Table S7). 

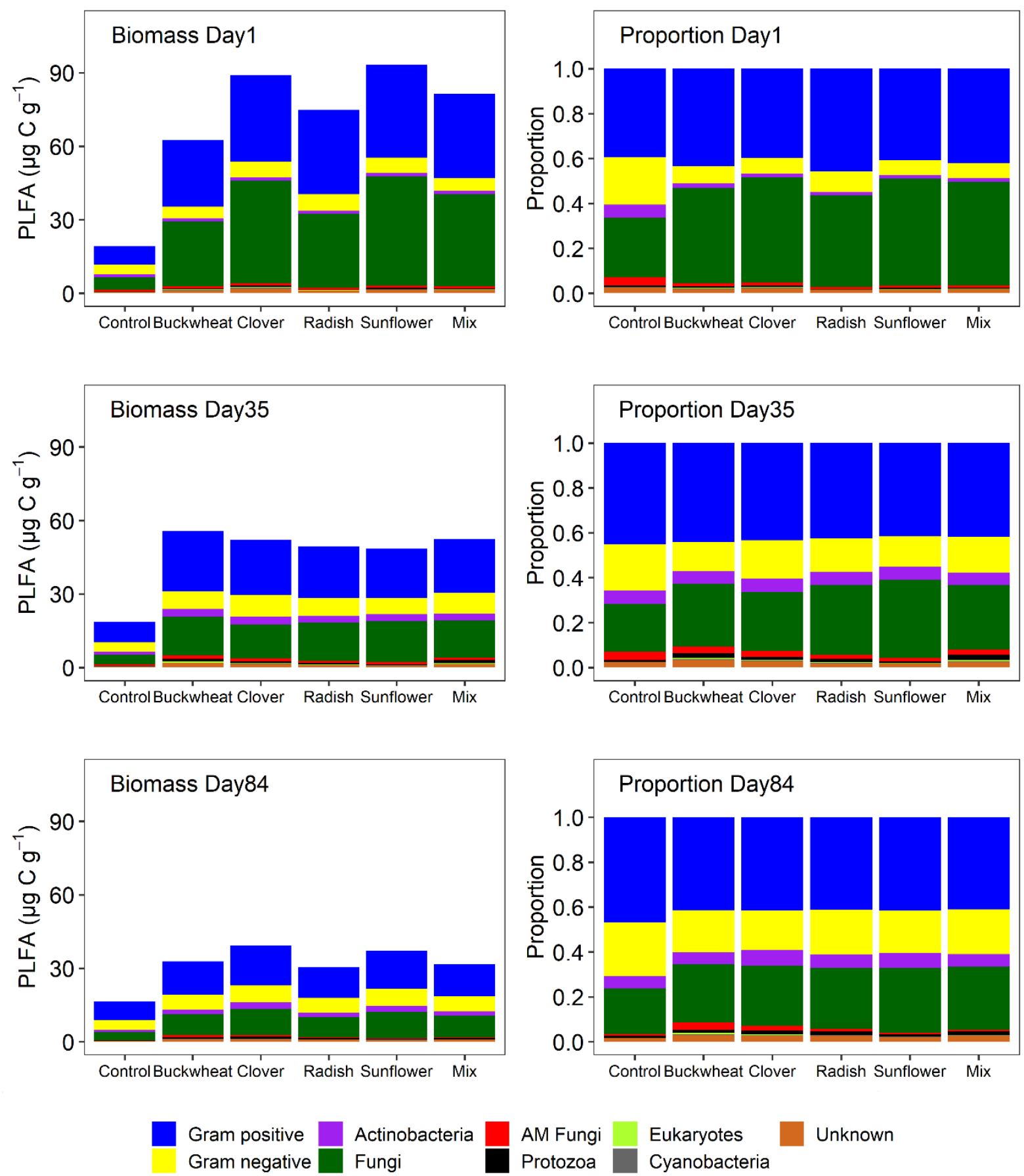

Figure 2 PLFA biomass $\left(\mu g \mathrm{C} \mathrm{g}^{-1}\right)$ and proportion in all treatments at day 1, 35 and 84. Mix is the quaternary mixture of buckwheat, clover, radish and sunflower containing $25 \%(w / w)$ of all four residues. Control is soil without any addition. AM fungi is arbuscular mycorrhiza fungi. Fungi or protozoa are not included in eukaryotes, and Actinobacteria is not included in the Gram-positive bacteria. $n=4$. 


\subsection{Changes of microbial community structure under different crop residues over time}

Adding cover crop residues significantly $(P<0.001)$ altered the soil microbial community structure regardless of the species of cover crop (Figure 2 and 3 and Table 2). Compared to the unamended control, the soil microbial communities in the cover crop residue treatments had a significantly $(P<0.001)$ greater relative abundance of fungi, and a significantly $(P<0.001)$ lower relative abundance of Gram-negative bacteria, arbuscular mycorrhizal fungi and Actinobacteria (Table S5). Incorporation of buckwheat, radish and the quaternary mixture significantly $(P<0.05)$ increased the relative abundance of Gram-positive bacteria, whereas no significant effects were found due to the addition of sunflower or clover residues. Focussing just on the treatments receiving cover crop residues revealed that soil microbial community composition was significantly different $(P<0.001)$ for all pairwise comparisons (Table 2). The residues of buckwheat or sunflower led to the development of microbial communities with the greatest dissimilarity between each other than any other comparison in this experiment. A significant $(P<0.001)$ difference in microbial community composition was found between the three time points, with a greater difference between day 1 and day 35 or 84 than between day 35 and day 84 (Table 2). 
Table 2 ANOSIM results ( $R$ value and $P$ value) of pairwise comparisons of the soil microbial community composition (PLFA profile) between different treatments or different time points after applying cover crops.

\begin{tabular}{|c|c|c|}
\hline & $R$ value & $P$ value \\
\hline Control/ Mix & 0.979 & $<0.001$ \\
\hline Control/ Radish & 0.844 & $<0.001$ \\
\hline Control/ Sunflower & 0.990 & $<0.001$ \\
\hline Control/Buckwheat & 0.972 & $<0.001$ \\
\hline Control/Clover & 0.903 & $<0.001$ \\
\hline Mix/ Radish & 0.285 & $<0.001$ \\
\hline Mix/Sunflower & 0.785 & $<0.001$ \\
\hline Mix/Buckwheat & 0.847 & $<0.001$ \\
\hline Mix/Clover & 0.688 & $<0.001$ \\
\hline Buckwheat/ Clover & 0.712 & $<0.001$ \\
\hline Buckwheat/ Radish & 0.743 & $<0.001$ \\
\hline Buckwheat/ Sunflower & 0.944 & $<0.001$ \\
\hline Clover/ Radish & 0.628 & $<0.001$ \\
\hline Clover/ Sunflower & 0.826 & $<0.001$ \\
\hline Radish/ Sunflower & 0.618 & $<0.001$ \\
\hline Day 1/Day 35 & 0.939 & $<0.001$ \\
\hline Day 1/ Day 84 & 0.977 & $<0.001$ \\
\hline Day 35/ Day 84 & 0.740 & $<0.001$ \\
\hline
\end{tabular}



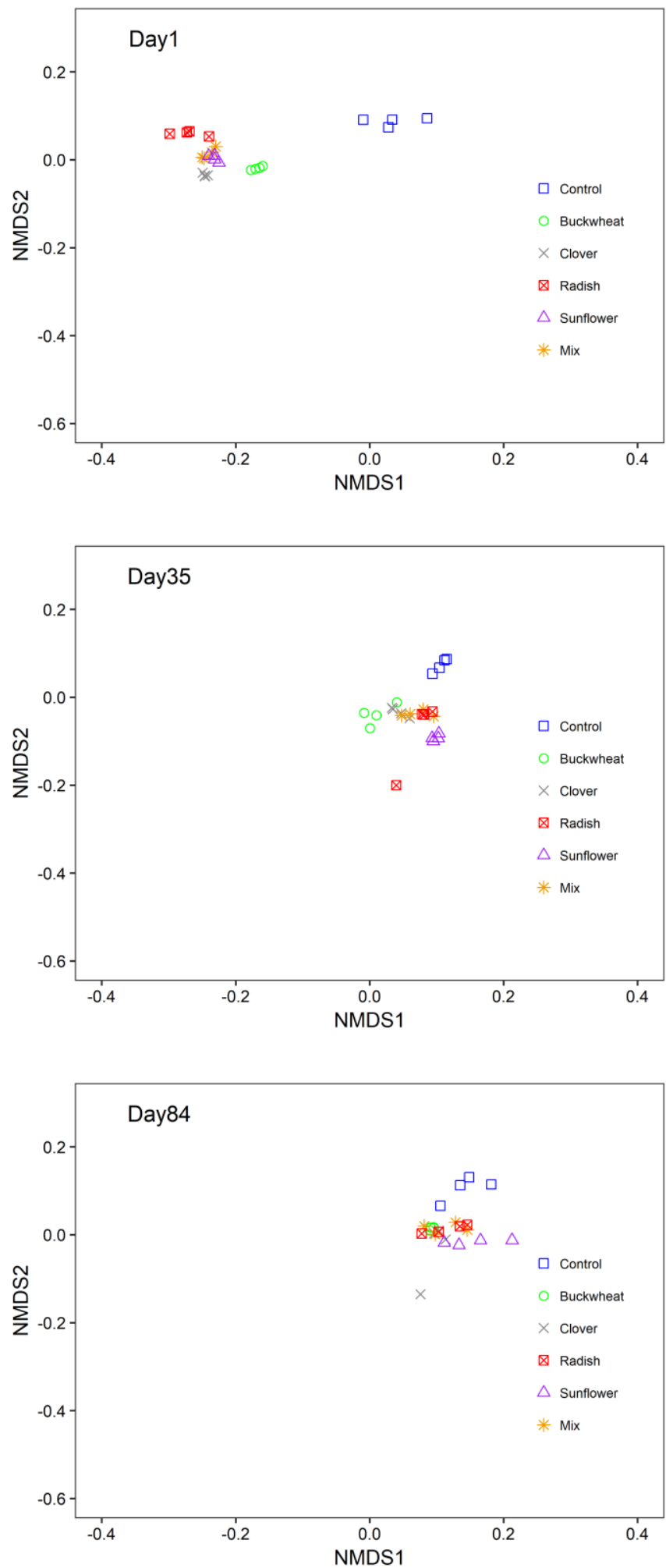

Figure 3 Microbial community structure in Day 1, Day 35, Day 84. Non-metric multidimensional scaling (NMDS) based on Bray-Curtis distance analysis of Hellinger transformed abundance of phospholipid fatty acid (PLFA) biomarkers. Dots are samples $(n=4)$. Stress $=0.0929$, $R^{2}=0.991$. 
3.3 Difference between mixture and the average of four individual cover crop residues

Compared to the average of the four individual cover crop residue treatments, the soil respiration rate was not significantly higher in the quaternary mixture treatment when all measurements are considered (Figure 4 and Table S6). However, during the period 30 to 84 days after adding cover crop residues, the soil respiration rate in the mixture treatment was significantly $(P<0.05)$ greater by $57.61 \mu \mathrm{g} \mathrm{C} \mathrm{g}{ }^{-1} \mathrm{~h}^{-1}$ than the average of four individual residues (Figure 4 and Table S6).

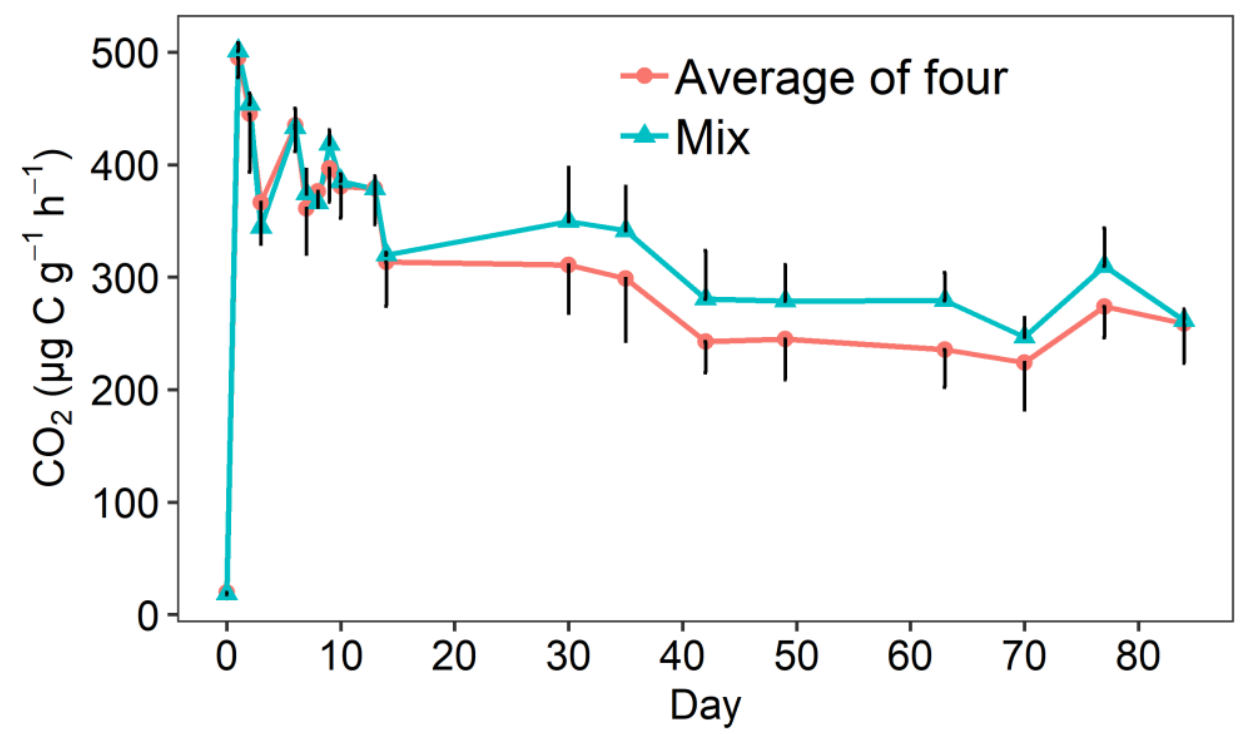

Figure $4 \quad$ The comparison of soil respiration rate between soils amended with the cover crop residue mixture $(n=4)$ and the average of four treatments amended with the residues of individual cover crop species ( $n=4 \times 4=16$ ). Mean and error bar (standard deviation). To aid visualization, the error bar for mixture is positive whereas for the average of four is negative.

The mixture treatment had a slightly, but not statistically significant, greater total microbial biomass than the average of the four individuals at 1 and 35 days after cover crop residue application, but a lower soil microbial biomass after 84 days (Figure 5). The biomass of fungi and Gram-positive bacteria were slightly greater in the quaternary mixture treatment than 
the average of the four individual cover crop treatments one day after residue incorporation (Figure 5), but there was no overall significant difference between the mixture treatment and the average of four individual treatments across the three time points (Table S6). Although different microbial biomarkers responded to the mixture differently, none of these differences were significant (Figure S2).

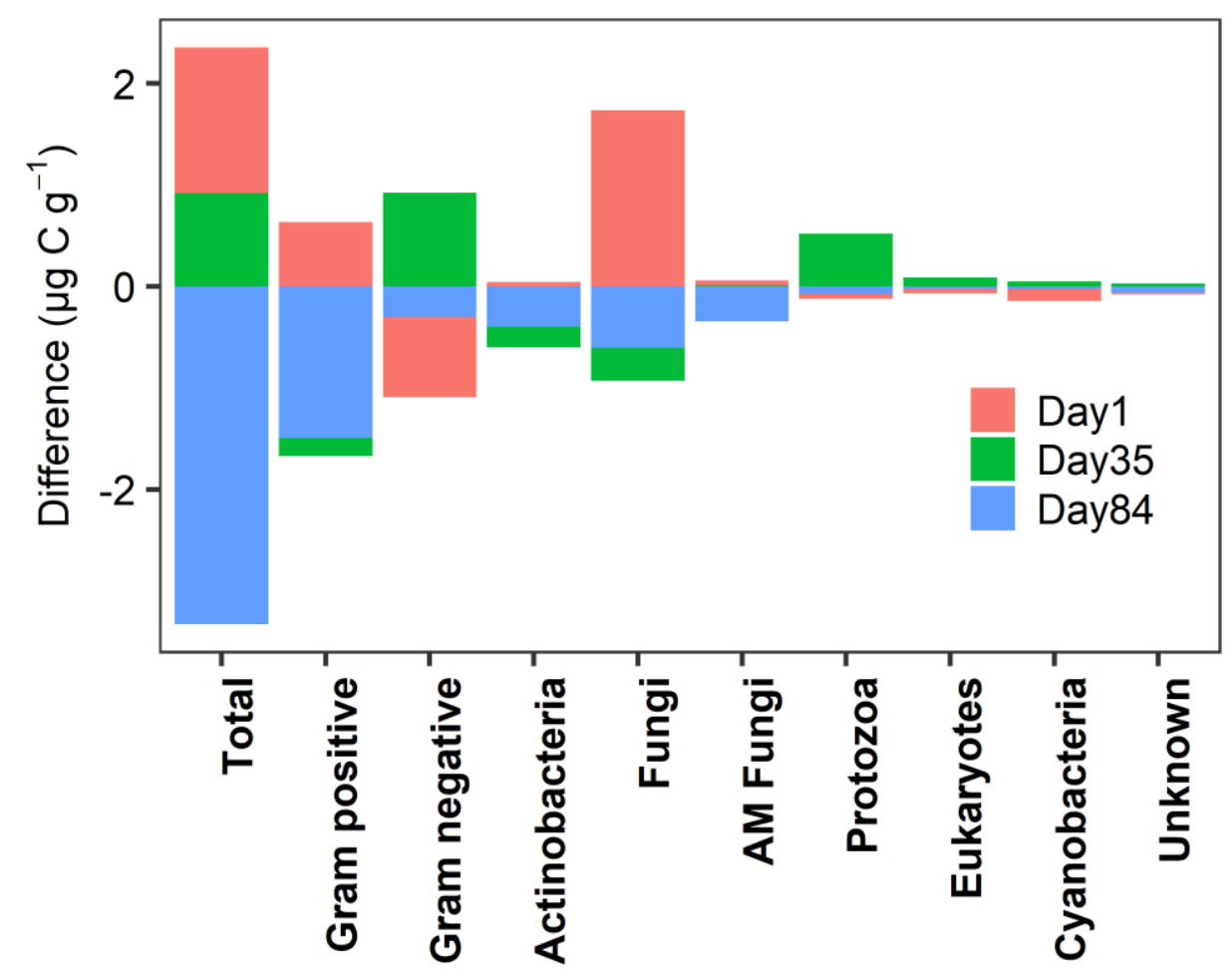

Figure $5 \quad$ Mass difference of microbial groups between soils amended with the cover crop residue mixture $(n=4)$ and the average of four treatments amended with the residues of individual cover crop species ( $n=4 \times 4=16$ ) over 84 days. Positive value means mixture has greater biomass than the average of the four individuals, and vice versa.

\section{Discussion}

\subsection{Cover crop residues increased soil respiration and microbial biomass}

The rapid elevation in respiration rate following a one-time addition of cover crop residues

(Figure 1), compared to unamended soil, reflects an intensive period of decomposition when 
the most labile components of plant residues were rapidly mineralised within hours of substrate addition, and this flush of microbial activity is not an uncommon observation after plant residue addition (Blagodatskaya et al. 2009). The highest respiration rate was found in the treatment with sunflower which also had the lowest $\mathrm{C} / \mathrm{N}$ ratio, confirming low $\mathrm{C} / \mathrm{N}$ ratio plant residues can be more easily mineralised by soil microorganisms (Zhang et al. 2008). When plant residues are decomposed, available nutrients and organic compounds can be quickly assimilated into microbial biomass (Bonanomi et al. 2017). This is why we observed a large increase of PLFA biomass in all the treatments receiving cover crop residues.

We also observed a greater fungi to bacteria ratio at the beginning of the degradation process, confirming that fungi are capable of faster exploitation of fresh substrates than bacteria, particularly Gram-negative bacteria (Keiblinger et al. 2010). This is similar to previous work which found a relatively greater increase in fast-growing fungi that specialise in metabolising C-rich material than bacteria (de Graaff et al. 2010). Fungi and bacteria apply different feeding strategies. Bacteria are more competitive in decomposing simple carbohydrates (e.g. glucose) than fungi (Meidute et al. 2008), while the growth of fungi can be favoured by litters containing O-alkyl C groups in biopolymers such as polysaccharides and polypeptides (Bonanomi et al. 2017). With the help of hyphae, fungi may gain access to less accessible substrates, such as cellulose fibrils, which are unlikely to be decomposed by bacteria (De Boer et al. 2005). In fact, a fungi dominant community is more efficient at recycling energy from decomposing complex organic compounds than bacteria, and thus contributes to a soil ecosystem with greater microbial biomass (Sinsabaugh et al. 2013).

\subsection{Cover crop residues changed soil microbial community}


Our study revealed a significant $(P<0.001)$ separation between the soil microbial community structure of treatments which received cover crop residues and the unamended control treatment (Table 2 and Figure 3). This observation is consistent with a previous study that demonstrated that the incorporation of plant residues provides a rich resource to boost the growth of microorganisms and alter microbial community structure (Fanin et al. 2014). The relatively greater proportions of fungi and Gram-positive bacteria were mirrored by a decrease in the relative proportion of Gram-negative bacteria and Actinobacteria and AM fungi, suggesting saprotrophic fungi and Gram-positive bacteria are more efficient in assimilating available resources. Different cover crop residues induced different microbial community structures. The largest distinction was found between buckwheat and sunflower, which is attributed to them having the biggest difference in $\mathrm{C} / \mathrm{N}$ ratio, confirming that plantderived substrate biochemical composition selects microbial community composition (Fanin et al. 2014).

By the end of the incubation, the difference between the soil microbial community in the control treatment and the treatments where cover crop residues were applied was smaller than the difference just one day after application. This return indicates a shift from a stochastic stage where residue inputs drive succession, to a deterministic phase where soil environmental factors play major roles in microbial succession (Dini-Andreote et al. 2015). Moreover, with the decomposition of plant residues, the life history strategy of the microbial communities may change from assimilating resources into biomass to the resource acquisition strategy in which more energy will be spent on producing extracellular enzymes to decompose complex resources rather than community succession or evolution (Malik et al. 2020). 


\subsection{The mixture delivered different effects on microbial respiration and community}

Our results found no significant overall difference in $\mathrm{CO}_{2}$ flux between the quaternary mixture of cover crop residues and the average of the four individual residues over 84 days of incubation (Figure 4), indicating that a mixture of crop residues results in an overall additive effect on crop residue degradation over time. This is consistent with a previous study that examined the decomposition of litters which contrasted in their specific rate of decomposition but decomposed at a rate that was additive when in a mixture (Wardle et al. 2006). The $\mathrm{C} / \mathrm{N}$ ratios of plant residues in our study are all less than 25 , indicating that $\mathrm{N}$ should not limit microbial decomposition of plant residues (Cuchietti et al. 2014). Since the amount of added $\mathrm{C}$ is the same in the mixture and the average of the four individual residues (both are $9.71 \mathrm{mg} \mathrm{C} \mathrm{g}^{-1}$ soil), it is not surprising that the decomposition rate in the mixture is similar to the average of four individual species.

Our study found a synergistic effect of the quaternary mixture of cover crop residues compared to the average of the four individual cover crop residues on soil respiration between 30 and 84 days after residue application. Our results are consistent with previous studies reporting that synergistic effects become stronger and more frequent as decomposition proceeds, which suggests that incubation time is an important factor to capture the additive or non-additive effect from the mixture (Wu et al. 2013; Santonja et al. 2015). Some authors have divided organic matter into labile and recalcitrant pools to explain decomposition rates (Chen and Frank 2020). Labile pools typically degrade faster than the recalcitrant pools. The reason why we observe a synergistic interaction of cover crop residues on soil respiration only in the latter stages of our experiment ( 30 to 84 days) may be because the interaction only occurs during the decomposition of the recalcitrant pool. 
Antagonistic or synergistic effects on the decomposition of recalcitrant C-pools could occur because the presence of certain compounds within one plant residue that promotes or inhibits the decomposition of other parts of a plant residue mixture (Gessner et al. 2010). Consequently, the trade-off between this inhibition or promotion determines the overall rate of decomposition (Wu et al. 2013). The relative balance of antagonistic and synergistic effects could result in an overall additive effect (Wu et al. 2013). As resource and microbial community composition shifts as decomposition progresses, stoichiometric requirements for microbial catabolic and anabolic process can also shift, and potentially influence microbial C use efficiency with consequences for the amount of respired $\mathrm{CO}_{2}$ (Sinsabaugh et al. 2013).

Although each plant residue induced a distinct microbial community structure, the incorporation of a mixture of cover crop residues did not generate major or statistically significant changes in the composition of the soil microbial community, compared to the average of the four communities in the soils which received individual cover crop residues (Figure 3). This suggests that, while plant residue identity is an important driver of soil microbial community, the diversity of plant residues per se might not be (Ball et al. 2009). One reason could be limited communication between microbial "hotspots" associated with individual plant residues due to spatial isolation of these "hotspots". Heterogenous pore space in the soil system limits the diffusion of nutrients and water between different "hotspots", and thus weakens the coevolutionary relationship between microbial communities (Tecon and Or 2017). Additionally, the overarching role of soil environmental conditions might override the effects of plant residue diversity on microbial community (Wardle et al. 2006). 
We did not observe a synergistic effect of the cover crop residue mixture on the soil microbial community during the period 30 to 84 days when a synergistic effect on soil respiration was observed, which could be attributed to the dynamic $C$ allocation strategy of microbial communities. Microorganisms allocate $\mathrm{C}$ to form extracellular enzymes, polysaccharides and other polymeric substances, and adjust osmolytes to combat environment changes and increase energy use efficiency, which may not necessarily change their community profile (Schimel and Schaeffer 2012). A recent study also found that a mixture of plant residues did not change microbial biomass but did increase microbial activity, compared to monocultures, indicating a strong phenotypic plasticity in the resident microbial communities (Drost et al. 2020). A diverse array of substrates may enhance synergistic microbial interactions between the resident communities. For example, fungi may facilitate the penetration of bacteria into a plant residue-associated "hotspot" where both can degrade polymer and accelerate plant residue decomposition, but may not change microbial cell membrane composition, as measured by the PLFA method (Gessner et al. 2010). Increasing the diversity of substrates available to the soil microbial communities may activate the metabolism of dormant microbial communities (Jones and Lennon 2010). These physiological changes in the soil microbial community, such as the transformation of dormant microorganisms to an active state and subsequent enhanced microbial connection/interaction, may not be expressed by differences in PLFA profiles. This study cannot rule out that the synergistic effect of the residue mixture on respiration may come as a result of an enhanced "priming effect" on the decomposition of native soil organic matter and necromass. It is reported that a sunflower-wheat mixture could induce a greater positive priming effect than the sunflower alone (Pausch et al. 2013). It is a possibility that interspecific interaction between extracellular enzymes produced by microbial communities to depolymerise different components of the mixture may also 
depolymerise native organic matter and thus enhance microbial metabolism and stimulate $\mathrm{CO}_{2}$ flux. Future research applying isotopic techniques to trace the fate of added $\mathrm{C}$, investigating the metabolically active microbial communities will help us to further understand reasons for the observed synergistic effects of cover crop residue mixtures on soil respiration.

\subsection{Implications of our findings}

The implications of our findings are that soil functions may be enhanced through the combination of plants from different plant families in a polyculture, compared to the respective monocultures, without altering the composition of the soil microbial community. In arable cropping systems there are three primary means to achieving plant diversification: (i) diversifying crop rotations, (ii) intercropping, and (iii) using cover crops. Crop rotations are a means of increasing plant diversity temporally (and spatially across a farm). However, the crops that farmers choose to plant is driven primarily by market forces, so crop selection is highly constrained. Planting two or more crops simultaneously (intercropping) offers opportunities to increase plant diversity. However, the choice of crops to intercrop is also highly constrained because species must be carefully selected to ensure they are compatible with each other. Cover crops are grown as part of a crop rotation during periods of the rotation when the soil would otherwise be bare. They are primarily grown to improve soil health for the following cash crops and to provide environmental benefits. Unlike rotation diversification and intercropping, cover crops offer a promising means to combine a diverse mixture of plants from a variety of different plant families. In theory, any combination of plant families could be combined without fundamentally changing how or when the preceding or 
proceeding cash crop is managed or harvested. Therefore, cover crops are the most flexible means to increasing plant diversity on arable farms.

The science underpinning decisions regarding which plants to combine in a cover crop mixture is in its infancy (Chapagain et al. 2020). Particular plants are included because they are known to deliver specific functions. For example, the four plants chosen in this experiment are often combined because they deliver different functions to each other (i.e. buckwheat improves phosphorus efficiency, clover supplies $\mathrm{N}$ to subsequent cash crop, radish alleviates soil compaction, and sunflower provides considerable aboveground biomass to feed soil microorganisms after incorporation). We show here that, as well as these individual functions delivered by individual plants, these plants can interact to enhance the deliver of soil functions beyond that expected by the individual plants. Our data therefore provides evidence to support farmers growing cover crop mixtures.

\section{Conclusion}

Our results demonstrated cover crop residues significantly $(P<0.001)$ increased microbial biomass and soil respiration and altered the soil microbial community structure. Fungi and Gram-positive bacteria were the most responsive microbial groups to plant residue additions. The mixture of cover crop residues (comprising $25 \%$ by mass of each of the four individual residues) significantly $(P<0.05)$ increased soil respiration rate during the period 30 to 84 days after residue incorporation, compared to the average of the four individual residues, but there was no significant difference in soil microbial biomass or composition observed. Nonadditive effects are strongly influenced by time, highlighting the importance of microbial life history strategies after exposure to crop residue mixtures. This study suggests that mixtures of cover crops could enhance microbial activity beyond that observed in soils receiving the 
residues of individual cover crop residues without altering soil microbial community composition.

\section{Conflict of Interest:}

The authors declare that they have no conflict of interest.

\section{Declaration of Funding}

This research was supported by a Biotechnology and Biological Sciences Research Council New Investigator Grant (BB/R006989/1) awarded to Tom Sizmur.

\section{Acknowledgements}

The authors wish to thank Kings Crops, a division of Frontier Agriculture Ltd, for supplying cover crop seed. We acknowledge the assistance of Anne Dudley, Karen Gutteridge, Fengjuan Xiao, Marta O’Brian, Sean Coole with laboratory analysis, and Dedy Antony, Alex Adetunji Adekanmbi and Chinonso Chukwuma Ogbuagu with soil sampling.

\section{Data Availability}

The data that support this study are available in Mendeley Data doi: 10.17632/vck9sycfhs.1

\section{References}

Abdalla M, Hastings A, Cheng K, Yue Q, Chadwick D, Espenberg M, Truu J, Rees RM, Smith P (2019) A critical review of the impacts of cover crops on nitrogen leaching, net greenhouse gas balance and crop productivity. Global Change Biology 25, 2530-2543. doi:10.1111/gcb.14644.

Adekanmbi AA, Shaw LJ, Sizmur T (2020) Effect of Sieving on Ex Situ Soil Respiration of Soils from Three Land Use Types. Journal of Soil Science and Plant Nutrition. 
doi:10.1007/s42729-020-00177-2.

Ball BA, Bradford MA, Coleman DC, Hunter MD (2009) Linkages between below and aboveground communities: Decomposer responses to simulated tree species loss are largely additive. Soil Biology and Biochemistry 41, 1155-1163. doi:10.1016/j.soilbio.2009.02.025.

Blagodatskaya E V., Blagodatsky SA, Anderson TH, Kuzyakov Y (2009) Contrasting effects of glucose, living roots and maize straw on microbial growth kinetics and substrate availability in soil. European Journal of Soil Science 60, 186-197. doi:10.1111/j.13652389.2008.01103.x.

De Boer W, Folman LB, Summerbell RC, Boddy L (2005) Living in a fungal world: Impact of fungi on soil bacterial niche development. FEMS Microbiology Reviews 29, 795-811. doi:10.1016/j.femsre.2004.11.005.

Bonanomi G, Cesarano G, Lombardi N, Motti R, Scala F, Mazzoleni S, Incerti G (2017) Litter chemistry explains contrasting feeding preferences of bacteria, fungi, and higher plants. Scientific Reports 7, 9208. doi:10.1038/s41598-017-09145-w.

Chapagain T, Lee EA, Raizada MN (2020) The potential of multi-species mixtures to diversify cover crop benefits. Sustainability (Switzerland) 12, doi:10.3390/su12052058.

Chapman SK, Newman GS (2010) Biodiversity at the plant-soil interface: Microbial abundance and community structure respond to litter mixing. Oecologia 162, 763-769. doi:10.1007/s00442-009-1498-3.

Chen J, Frank DA (2020) Herbivores stimulate respiration from labile and recalcitrant soil carbon pools in grasslands of Yellowstone National Park. Land Degradation and Development 31, 2620-2634. doi:10.1002/ldr.3656.

Chen J, Luo Y, Van Groenigen KJ, Hungate BA, Cao J, Zhou X, Wang R wu (2018) A keystone microbial enzyme for nitrogen control of soil carbon storage. Science Advances 4, 2-8. doi:10.1126/sciadv.aaq1689.

Cuchietti A, Marcotti E, Gurvich DE, Cingolani AM, Pérez Harguindeguy N (2014) Leaf litter 
mixtures and neighbour effects: Low-nitrogen and high-lignin species increase decomposition rate of high-nitrogen and low-lignin neighbours. Applied Soil Ecology 82, 44-51. doi:10.1016/j.apsoil.2014.05.004.

Daryanto S, Fu B, Wang L, Pierre-André J, Zhao W (2018) Quantitative synthesis on the ecosystem services of cover crops. Earth-Science Reviews 185, 357-373. doi:10.1016/j.earscirev.2018.06.013.

Dini-Andreote F, Stegen JC, van Elsas JD, Salles JF (2015) Disentangling mechanisms that mediate the balance between stochastic and deterministic processes in microbial succession. Proceedings of the National Academy of Sciences 112, E1326-E1332. doi:10.1073/pnas.1414261112.

Drost SM, Rutgers M, Wouterse M, de Boer W, Bodelier PLE (2020) Decomposition of mixtures of cover crop residues increases microbial functional diversity. Geoderma 361, 114060. doi:10.1016/j.geoderma.2019.114060.

Eisenhauer N, Schulz W, Scheu S, Jousset A (2013) Niche dimensionality links biodiversity and invasibility of microbial communities. Functional Ecology 27, 282-288. doi:10.1111/j.1365-2435.2012.02060.x.

Fanin N, Hättenschwiler S, Fromin N (2014) Litter fingerprint on microbial biomass, activity, and community structure in the underlying soil. Plant and Soil 379, 79-91. doi:10.1007/s11104-014-2051-7.

Frostegård Å, Tunlid A, Bååth E (1993) Phospholipid Fatty Acid Composition, Biomass, and Activity of Microbial Communities from Two Soil Types Experimentally Exposed to Different Heavy Metals. Applied and Environmental Microbiology 59, 3605-3617. doi:10.1128/AEM.59.11.3605-3617.1993.

Gartner TB, Cardon ZG (2004) Decomposition dynamics in mixed-species leaf litter. Oikos 104, 230-246. doi:10.1111/j.0030-1299.2004.12738.x.

Gessner MO, Swan CM, Dang CK, McKie BG, Bardgett RD, Wall DH, Hättenschwiler S (2010) Diversity meets decomposition. Trends in Ecology \& Evolution 25, 372-380. 
doi:10.1016/j.tree.2010.01.010.

de Graaff MA, Classen AT, Castro HF, Schadt CW (2010) Labile soil carbon inputs mediate the soil microbial community composition and plant residue decomposition rates. New Phytologist 188, 1055-1064. doi:10.1111/j.1469-8137.2010.03427.x.

Jones SE, Lennon JT (2010) Dormancy contributes to the maintenance of microbial diversity. Proceedings of the National Academy of Science 107, 5881-5886. doi:10.1073/pnas.0912765107.

Keiblinger KM, Hall EK, Wanek W, Szukics U, Hämmerle I, Ellersdorfer G, Böck S, Strauss J, Sterflinger K, Richter A, Zechmeister-Boltenstern S (2010) The effect of resource quantity and resource stoichiometry on microbial carbon-use-efficiency. FEMS Microbiology Ecology 73, 430-440. doi:10.1111/j.1574-6941.2010.00912.x.

Kim N, Zabaloy MC, Guan K, Villamil MB (2020) Do cover crops benefit soil microbiome? A meta-analysis of current research. Soil Biology and Biochemistry 142, 107701. doi:10.1016/j.soilbio.2019.107701.

Malik AA, Martiny JBH, Brodie EL, Martiny AC, Treseder KK, Allison SD (2020) Defining traitbased microbial strategies with consequences for soil carbon cycling under climate change. The ISME Journal 14, 1-9. doi:10.1038/s41396-019-0510-0.

Manzoni S, Jackson RB, Trofymow JA, Porporato A (2008) The Global Stoichiometry of Litter Nitrogen Mineralization. Science 321, 684-686. doi:10.1126/science.1159792.

Meidute S, Demoling F, Bååth E (2008) Antagonistic and synergistic effects of fungal and bacterial growth in soil after adding different carbon and nitrogen sources. Soil Biology and Biochemistry 40, 2334-2343. doi:10.1016/J.SOILBIO.2008.05.011.

Oksanen J, Blanchet FG, Friendly M, Kindt R, Legendre P, McGlinn D, Minchin PR, O'Hara RB, Simpson GL, Solymos P, Stevens MHH, Szoecs E, Wagner H (2019) vegan: Community Ecology Package. https://cran.r-project.org/package=vegan.

Pausch J, Zhu B, Kuzyakov Y, Cheng W (2013) Plant inter-species effects on rhizosphere priming of soil organic matter decomposition. Soil Biology and Biochemistry 57, 91-99. 
doi:10.1016/j.soilbio.2012.08.029.

Pinheiro J, Bates D, DebRoy S, Sarkar D, R Core Team (2018) Linear and Nonlinear Mixed Effects Models, R package. https://cran.r-project.org/package=nlme.

R Core Team (2018) R: A Language and Environment for Statistical Computing. https://www.rproject.org/.

Redin M, Recous S, Aita C, Dietrich G, Skolaude AC, Ludke WH, Schmatz R, Giacomini SJ (2014) How the chemical composition and heterogeneity of crop residue mixtures decomposing at the soil surface affects $C$ and $N$ mineralization. Soil Biology and Biochemistry 78, 6575. doi:10.1016/j.soilbio.2014.07.014.

Santonja M, Fernandez C, Gauquelin T, Baldy V (2015) Climate change effects on litter decomposition: intensive drought leads to a strong decrease of litter mixture interactions. Plant and Soil 393, 69-82. doi:10.1007/s11104-015-2471-z.

Schimel JP, Hättenschwiler S (2007) Nitrogen transfer between decomposing leaves of different $\mathrm{N}$ status. Soil Biology and Biochemistry 39, 1428-1436. doi:10.1016/j.soilbio.2006.12.037.

Schimel JP, Schaeffer SM (2012) Microbial control over carbon cycling in soil. Frontiers in Microbiology 3, 1-11. doi:10.3389/fmicb.2012.00348.

Sinsabaugh RL, Manzoni S, Moorhead DL, Richter A (2013) Carbon use efficiency of microbial communities: stoichiometry, methodology and modelling. Ecology letters 16, 930-9. doi:10.1111/ele.12113.

Sizmur T, Tilston EL, Charnock J, Palumbo-Roe B, Watts MJ, Hodson ME (2011) Impacts of epigeic, anecic and endogeic earthworms on metal and metalloid mobility and availability. Journal of Environmental Monitoring 13, 266-273. doi:10.1039/c0em00519c.

Talbot JM, Treseder KK (2012) Interactions among lignin, cellulose, and nitrogen drive litter chemistry-decay relationships. Ecology 93, 345-354. doi:10.1890/11-0843.1.

Tecon R, Or D (2017) Biophysical processes supporting the diversity of microbial life in soil. 
FEMS Microbiology Reviews 41, 599-623. doi:10.1093/femsre/fux039.

Wardle DA, Yeates GW, Barker GM, Bonner KI (2006) The influence of plant litter diversity on decomposer abundance and diversity. Soil Biology and Biochemistry 38, 1052-1062. doi:10.1016/j.soilbio.2005.09.003.

Wink M (2008) Plant Secondary Metabolism: Diversity, Function and its Evolution. Natural Product Communications 3, 1205-1216. doi:10.1177/1934578X0800300801.

Wu D, Li T, Wan S (2013) Time and litter species composition affect litter-mixing effects on decomposition rates. Plant and Soil 371, 355-366. doi:10.1007/s11104-013-1697-x.

Ye J, Perez PG, Zhang R, Nielsen S, Huang D, Thomas T (2018) Effects of different C/N ratios on bacterial compositions and processes in an organically managed soil. Biology and Fertility of Soils 54, 137-147. doi:10.1007/s00374-017-1246-5.

Zhang D, Hui D, Luo Y, Zhou G (2008) Rates of litter decomposition in terrestrial ecosystems: global patterns and controlling factors. Journal of Plant Ecology 1, 85-93. doi:10.1093/jpe/rtn002.

Zheng W, Zhao Z, Gong Q, Zhai B, Li Z (2018) Effects of cover crop in an apple orchard on microbial community composition, networks, and potential genes involved with degradation of crop residues in soil. Biology and Fertility of Soils 54, 743-759. doi:10.1007/s00374-018-1298-1. 


\section{Supplementary materials}

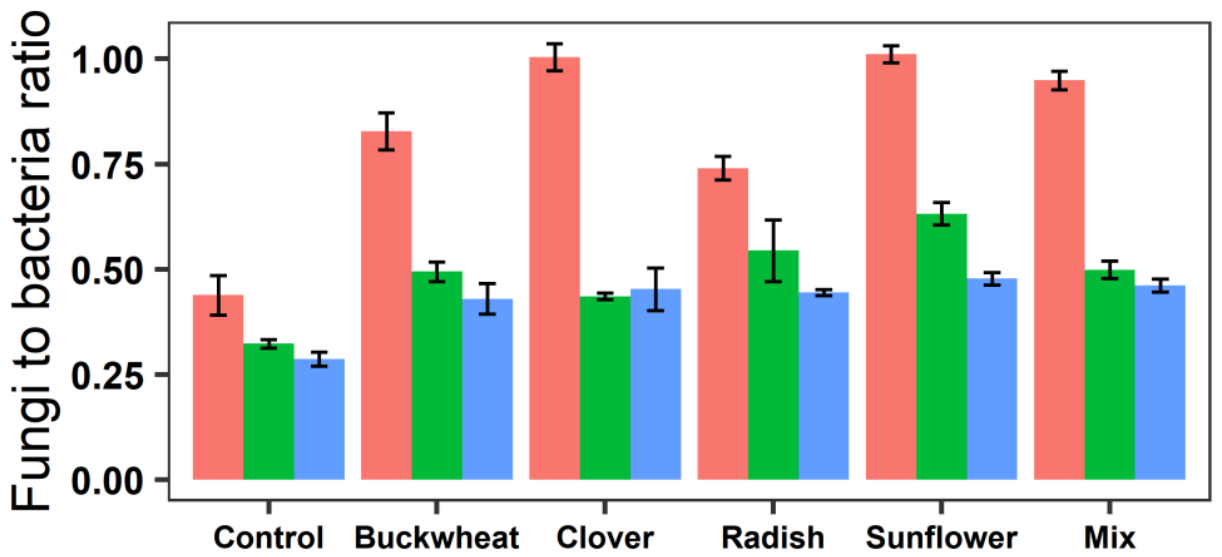

Day1 Day35 Day84

Figure S1 The ratio of fungi to bacteria in all the treatments. Means and standard deviation (error bars).

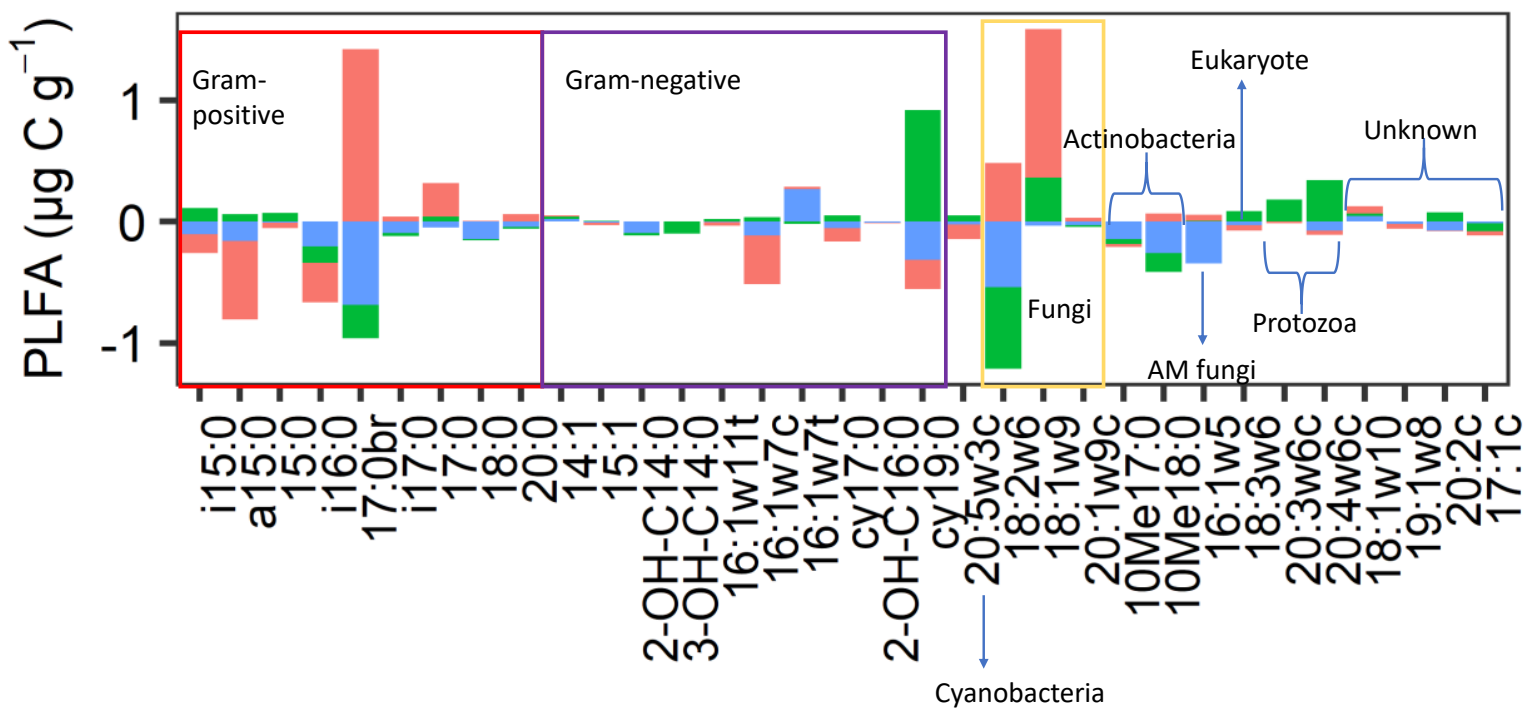

Day1 Day35 Day84

Figure S2 Mass difference of all measured biomarkers between the mixture and the average of the four individuals (buckwheat, clover, radish and sunflower). Positive value means 
biomarker's biomass is greater in the mixture than the average of the four individuals, and vice versa.
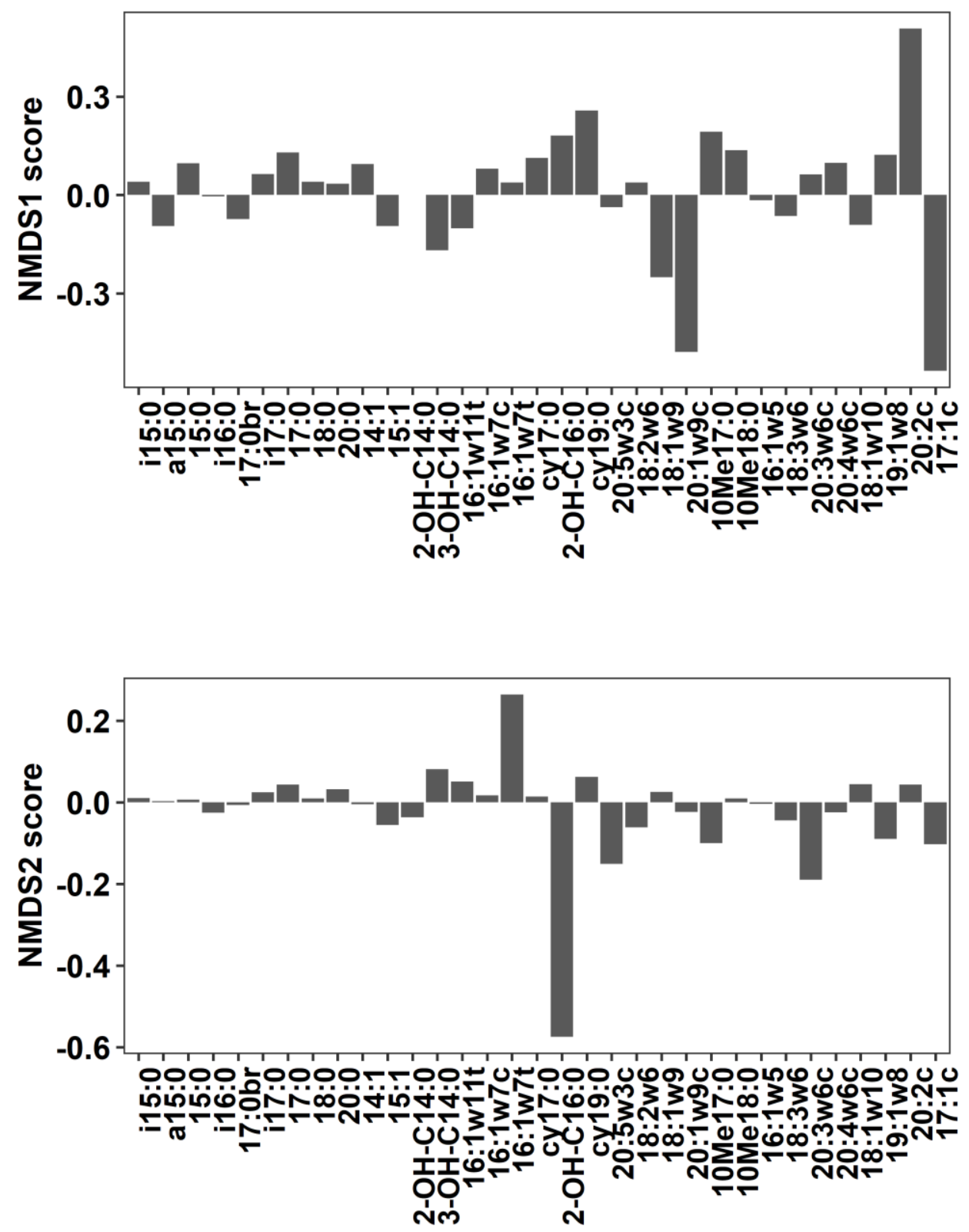

Figure S3 The scores of non-metric multidimensional scaling (NMDS) based on Bray-Curtis distance analysis of Hellinger transformed abundance of phospholipid fatty acid (PLFA) biomarkers. 
Table S1 The trace element contents of cover crop residues used in the experiment

\begin{tabular}{llllll}
\hline Element & Buckwheat & Clover & Radish & Sunflower & Mixture \\
\hline $\mathrm{Al}\left(\mathrm{mg} \mathrm{kg}^{-1}\right)$ & 205 & 243 & 381 & 82.0 & 229 \\
$\mathrm{Cd}\left(\mathrm{mg} \mathrm{kg}^{-1}\right)$ & 0.37 & 0.08 & 0.38 & 0.71 & 0.09 \\
$\mathrm{Co}\left(\mathrm{mg} \mathrm{kg}^{-1}\right)$ & 0.08 & 0.07 & 0.37 & 0.07 & 0.03 \\
$\mathrm{Cr}\left(\mathrm{mg} \mathrm{kg}^{-1}\right)$ & 23.0 & 21.0 & 52.0 & 7.00 & 25.0 \\
$\mathrm{Cu}\left(\mathrm{mg} \mathrm{kg}^{-1}\right)$ & 7.00 & 10.0 & 3.00 & 19.0 & 9.00 \\
$\mathrm{Fe}\left(\mathrm{mg} \mathrm{kg}^{-1}\right)$ & 354 & 484 & 816 & 209 & 462 \\
$\mathrm{Mn}\left(\mathrm{mg} \mathrm{kg}^{-1}\right)$ & 26.0 & 50.0 & 38.0 & 34.0 & 36.0 \\
$\mathrm{Na}\left(\mathrm{mg} \mathrm{kg}^{-1}\right)$ & 91.0 & 3420 & 1970 & 262 & 1390 \\
$\mathrm{Ni}\left(\mathrm{mg} \mathrm{kg}^{-1}\right)$ & 11.0 & 9.00 & 21.0 & 3.00 & 11.0 \\
$\mathrm{~Pb}\left(\mathrm{mg} \mathrm{kg}^{-1}\right)$ & 2.06 & 0.00 & 2.13 & 0.71 & 1.30 \\
$\mathrm{Zn}\left(\mathrm{mg} \mathrm{kg}^{-1}\right)$ & 153 & 47.0 & 44.0 & 109 & 89.0 \\
\hline
\end{tabular}

Table S2 The attribution of PLFA biomarkers to microbial groups

\begin{tabular}{ll}
\hline Microbial groups & PLFA biomarkers \\
\hline Gram-positive bacteria & i15:0, a15:0, 15:0, i16:0, i17:0, 17:0, 17:0br, 18:0, 20:0 \\
Gram-negative bacteria & $\begin{array}{l}\text { 14:1, 15:1, cy7:0, 16:1 } \omega 11 \mathrm{t}, 16: 1 \omega 7 \mathrm{c}, 16: 1 \omega 7 \mathrm{t}, \mathrm{cy} 17: 0, \mathrm{cy} 19: 0,2- \\
\text { OH-C14:0, 3-OH-C14:0, 2-OH-C16:0 } \\
\text { Fungi }\end{array}$ \\
18:2 $\omega 6,18: 1 \omega 9,20: 1 \omega 9 \mathrm{c}$ \\
Actinobacteria & $10 \mathrm{Me} 17: 0,10 \mathrm{Me} 18: 0$ \\
Eukaryote & $18: 3 \omega 6$ \\
AM fungi & $16: 1 \omega 5$ \\
Protozoa & $20: 3 \omega 6 \mathrm{c}, 20: 4 \omega 6 \mathrm{c}$ \\
Cyanobacteria & $20: 5 \omega 3 \mathrm{c}$ \\
Unknown & $18: 1 \omega 10,19: 1 \omega 8,20: 2 \mathrm{c}, 17: 1 \mathrm{c}$ \\
\hline
\end{tabular}


Table S3 Coefficients of linear mixed effects model analysing the fixed effects from different treatments and day as well as their interaction on soil respiration rate $\left(\mu \mathrm{g} \mathrm{C} \mathrm{g}^{-1} \mathrm{~h}^{-1}\right)$, fungi to bacteria ratio, and the biomass $\left(\mu \mathrm{g} \mathrm{C} \mathrm{g}{ }^{-1}\right.$ ) of total PLFA, fungi, Gram-positive bacteria, Gram-negative bacteria, eukaryote, protozoa, AM fungi, actinobacteria, cyanobacteria, and unknown microbial group. DF means degree of freedom. For all microbial group, the DF are the same as total PLFA. The effects are the effects of different treatments with a comparison to the control which received no cover crop residues. $* * *$, and $* * *$ means significant difference at $P<0.05,<0.01$, and $<0.001$. Abbreviations are $\mathrm{F} / \mathrm{B}$ ratio (fungi to bacteria ratio), $\mathrm{G}+\mathrm{bacteria}$ (Gram-positive bacteria), G- bacteria (Gram-negative bacteria), AMF (arbuscular mycorrhiza fungi).

\begin{tabular}{|c|c|c|c|c|c|c|c|c|c|c|c|c|c|c|}
\hline \multirow[t]{2}{*}{ Fixed term } & \multicolumn{2}{|l|}{ Respiration } & \multicolumn{2}{|l|}{ Total PLFA } & \multirow{2}{*}{$\begin{array}{l}\text { F/B ratio } \\
\text { Effects }\end{array}$} & \multirow{2}{*}{$\begin{array}{l}\text { Fungi } \\
\text { Effects }\end{array}$} & \multirow{2}{*}{$\begin{array}{l}\mathrm{G}+ \\
\text { bacteria } \\
\text { Effects }\end{array}$} & \multirow{2}{*}{$\begin{array}{l}\text { G- } \\
\text { bacteria } \\
\text { Effects }\end{array}$} & \multirow{2}{*}{$\begin{array}{l}\text { Eukaryote } \\
\text { Effects }\end{array}$} & \multirow{2}{*}{$\begin{array}{l}\text { Protozoa } \\
\text { Effects }\end{array}$} & \multirow{2}{*}{$\begin{array}{l}\text { AMF } \\
\text { Effects }\end{array}$} & \multirow{2}{*}{$\begin{array}{l}\text { Actinobacteria } \\
\text { Effects }\end{array}$} & \multirow{2}{*}{$\begin{array}{l}\text { Cyanobacteria } \\
\text { Effects }\end{array}$} & \multirow{2}{*}{$\begin{array}{l}\text { Unknown } \\
\text { Effects }\end{array}$} \\
\hline & Effects & DF & Effects & DF & & & & & & & & & & \\
\hline Intercept & 17.97 & 426 & $19.49 * * *$ & 42 & $0.42 * * *$ & $4.91^{*}$ & $7.90 * * *$ & $3.97 * * *$ & 0.031 & 0.138 & $0.786 * * *$ & $1.187^{* * *}$ & 0.015 & $0.549 * * *$ \\
\hline Buckwheat & $337.45^{* * *}$ & 18 & $45.51 * * *$ & 18 & $0.35^{* * *}$ & $20.47^{* * *}$ & $20.66^{* * *}$ & 1.47 & $0.236^{* *}$ & $0.553^{*}$ & 0.266 & 0.758 & $0.196 * * *$ & $0.904 * * *$ \\
\hline Clover & $340.28 * * *$ & 18 & $63.77^{* * *}$ & 18 & $0.46 * * *$ & $31.32 * * *$ & $25.77^{* * *}$ & $3.2 * * *$ & $0.192 * *$ & $0.526^{*}$ & 0.346 & 0.773 & $0.333 * * *$ & $1.307^{* * *}$ \\
\hline Radish & $371.82 * * *$ & 18 & $53.09 * * *$ & 18 & $0.30 * * *$ & $23.46^{* * *}$ & $25.02 * * *$ & $3.13^{* * *}$ & 0.055 & 0.223 & 0.032 & 0.587 & $0.071^{*}$ & $0.51^{*}$ \\
\hline Sunflower & $373.48 * * *$ & 18 & $66.07 * * *$ & 18 & $0.54 * * *$ & $34.75 * * *$ & $27.02 * * *$ & $2.25^{* *}$ & $0.135^{*}$ & 0.355 & 0.11 & 0.6 & $0.069 *$ & $0.775^{* *}$ \\
\hline Mix & $358.58 * * *$ & 18 & $59.16 * * *$ & 18 & $0.44 * * *$ & $28.83 * * *$ & $25.3 * * *$ & $2.3^{* *}$ & $0.159 *$ & $0.592 *$ & 0.289 & 0.705 & $0.096 * *$ & $0.882 * * *$ \\
\hline Day & 0.38 & 426 & -0.03 & 42 & -0.002 & -0.02 & 0 & 0 & 0 & 0 & $-0.007^{* *}$ & -0.003 & 0 & -0.003 \\
\hline Buckwheat*Day & $-2.34 * * *$ & 426 & $-0.33 * * *$ & 42 & $-0.003^{*}$ & $-0.19 * *$ & $-0.17 * * *$ & 0.02 & 0 & 0 & $0.009 *$ & 0.006 & $-0.001^{*}$ & 0 \\
\hline Clover*Day & $-2.36 * * *$ & 426 & $-0.54 * * *$ & 42 & $-0.004 * *$ & $-0.34 * * *$ & $-0.22 * * *$ & 0.01 & -0.001 & 0.001 & 0.004 & 0.016 & $-0.003 * * *$ & -0.007 \\
\hline Radish*Day & $-2.09 * * *$ & 426 & $-0.49 * * *$ & 42 & -0.002 & $-0.24 * * *$ & $-0.26 * * *$ & -0.01 & 0 & 0.003 & 0.002 & 0.009 & 0 & 0 \\
\hline Sunflower*Day & $-1.94 * * *$ & 426 & $-0.61 * * *$ & 42 & $-0.004 * *$ & $-0.37 * * *$ & $-0.26 * * *$ & 0.01 & -0.002 & -0.001 & -0.001 & 0.015 & 0 & -0.005 \\
\hline Mix*Day & $-1.77 * * *$ & 426 & $-0.55 * * *$ & 42 & $-0.004 * *$ & $-0.31 * * *$ & $-0.25 * * *$ & 0.01 & -0.001 & -0.001 & -0.001 & 0.006 & 0 & -0.004 \\
\hline
\end{tabular}


Table S4 Multiple pairwise comparison of the effect between different plant residues on respiration rate $\left(\mu \mathrm{C} \mathrm{g}^{-1} \mathrm{~h}^{-1}\right)$, fungi to bacteria ratio, and the biomass ( $\mu \mathrm{g} \mathrm{C} \mathrm{g}^{-1}$ ) of total PLFA, fungi, Gram-positive bacteria, Gram-negative bacteria, eukaryote, protozoa, AM fungi, actinobacteria, cyanobacteria, and unknown microbial group. ${ }^{*}, * *$, and $* * *$ means significant difference at $P<0.05,<0.01$, and $<0.001$. Abbreviations are $\mathrm{F} / \mathrm{B}$ ratio (fungi to bacteria ratio), G+ bacteria (Gram-positive bacteria), G- bacteria (Gram-negative bacteria), AMF (arbuscular mycorrhiza fungi).

\begin{tabular}{|c|c|c|c|c|c|c|c|c|c|c|c|c|}
\hline Comparison & Respiration & Total PLFA & $\mathrm{F} / \mathrm{B}$ ratio & Fungi & $\mathrm{G}+$ bacteria & G- bacteria & Eukaryote & Protozoa & AMF & Actinobacteria & Cyanobacteria & Unknown \\
\hline Mix/ Buckwheat & 36.93 & 4.831 & 0.052 & 3.650 & 1.305 & 0.600 & -0.100 & 0.026 & -0.379 & -0.046 & -0.049 & -0.176 \\
\hline Mix/ Clover & 34.62 & -5.082 & 0.006 & -1.470 & -1.658 & -0.767 & -0.033 & 0.011 & -0.281 & -0.480 & -0.119 & -0.284 \\
\hline Mix/Radish & -4.32 & 3.539 & 0.060 & 2.480 & 0.426 & -0.065 & 0.083 & 0.234 & 0.120 & 0.016 & 0.016 & 0.229 \\
\hline Mix/ Sunflower & -10.09 & -4.589 & -0.071 & -3.590 & -1.452 & 0.005 & 0.073 & 0.260 & 0.153 & -0.233 & 0.025 & 0.168 \\
\hline Buckwheat/ Clover & -2.31 & -9.913 & -0.047 & -5.120 & -2.963 & -1.367 & 0.068 & -0.014 & 0.099 & -0.435 & -0.070 & -0.107 \\
\hline Buckwheat/ Radish & -41.25 & -1.292 & 0.007 & -1.170 & -0.879 & -0.665 & $0.183^{* *}$ & 0.208 & $0.499 * *$ & 0.062 & 0.065 & 0.405 \\
\hline Buckwheat/ Sunflower & $-47.03^{*}$ & -9.419 & -0.123 & -7.240 & -2.757 & -0.595 & $0.173 * *$ & 0.234 & $0.532 * *$ & -0.188 & $0.074 * *$ & 0.344 \\
\hline Clover/ Radish & -38.94 & 8.621 & 0.054 & 3.950 & 2.084 & 0.701 & 0.115 & 0.223 & 0.401 & 0.496 & $0.135^{* * *}$ & $0.512^{*}$ \\
\hline Clover/Sunflower & $-44.71 *$ & 0.494 & -0.076 & -2.110 & 0.206 & 0.772 & 0.106 & 0.248 & $0.434^{*}$ & 0.247 & $0.143 * * *$ & $0.451 *$ \\
\hline Radish/ Sunflower & -5.78 & -8.127 & -0.130 & -6.070 & -1.878 & 0.070 & -0.010 & 0.026 & 0.033 & -0.249 & 0.009 & -0.061 \\
\hline
\end{tabular}


Table S5 Coefficients of linear mixed effects model analysing the fixed effects from different treatments and day as well as their interaction on relative abundance (proportion) of fungi, Gram-positive bacteria, Gram-negative bacteria, eukaryote, protozoa, AM fungi, actinobacteria, cyanobacteria, and unknown microbial group. For all microbial group, the DF (degree of freedom) are the same. The effects are the effects of different treatments with a comparison to the control which received no cover crop residues. ${ }^{*},{ }^{* *}$, and ${ }^{* * *}$ means significant difference at $P<0.05,<0.01$, and $<0.001$.

\begin{tabular}{|c|c|c|c|c|c|c|c|c|c|c|}
\hline Fixed term & DF & Fungi & Gram-positive bacteria & Gram-negative bacteria & Eukaryote & Protozoa & AM fungi & Actinobacteria & Cyanobacteria & Unknown \\
\hline Intercept & 42 & $0.255^{* * *}$ & $0.404 * * *$ & $0.204^{* * *}$ & 0.001 & 0.006 & $0.041 * * *$ & $0.061^{* * *}$ & 0.001 & $0.027 * * *$ \\
\hline Buckwheat & 18 & $0.141 * * *$ & $0.037 * * *$ & $-0.126 * * *$ & 0.003 & 0.005 & $-0.026 * * *$ & $-0.032 * * *$ & $0.003 * * *$ & -0.005 \\
\hline Clover & 18 & $0.168 * * *$ & 0.004 & $-0.113 * * *$ & 0.001 & 0.002 & $-0.026 * * *$ & $-0.036 * * *$ & $0.003 * * *$ & -0.004 \\
\hline Radish & 18 & $0.138 * * *$ & $0.050 * * *$ & $-0.110 * * *$ & 0.000 & -0.001 & $-0.029 * * *$ & $-0.035 * * *$ & 0.001 & $-0.013^{* *}$ \\
\hline Sunflower & 18 & $0.206 * * *$ & 0.005 & $-0.131 * * *$ & 0.000 & -0.001 & $-0.029 * * *$ & $-0.038 * * *$ & 0.000 & $-0.012 * *$ \\
\hline Mix & 18 & $0.170 * * *$ & $0.019 *$ & $-0.125 * * *$ & 0.001 & 0.005 & $-0.026 * * *$ & $-0.036 * * *$ & 0.001 & $-0.009 *$ \\
\hline Day & 42 & -0.001 & $0.001^{* * *}$ & $0.000 *$ & 0.000 & 0.000 & $0.000 * * *$ & 0.000 & 0.000 & $0.000 *$ \\
\hline Buckwheat*Day & 42 & $-0.001^{*}$ & $-0.001 * * *$ & $0.001^{* * *}$ & 0.000 & 0.000 & $0.001^{* * *}$ & $0.000 * *$ & 0.000 & $0.000 * * *$ \\
\hline Clover*Day & 42 & $-0.002 * *$ & $-0.001 * * *$ & $0.001 * * *$ & 0.000 & 0.000 & $0.000 * * *$ & $0.001 * * *$ & 0.000 & $0.000 *$ \\
\hline Radish*Day & 42 & -0.001 & $-0.001 * * *$ & $0.001 * * *$ & 0.000 & 0.000 & $0.000 * * *$ & $0.001 * * *$ & $0.000^{*}$ & $0.000 * * *$ \\
\hline Sunflower*Day & 42 & $-0.002 * *$ & $-0.001 * * *$ & $0.001 * * *$ & 0.000 & 0.000 & $0.000 * *$ & $0.001 * * *$ & 0.000 & $0.000 *$ \\
\hline Mix*Day & 42 & $-0.001^{*}$ & $-0.001 * * *$ & $0.001 * * *$ & 0.000 & 0.000 & $0.000 * *$ & $0.001 * * *$ & 0.000 & $0.000 * *$ \\
\hline
\end{tabular}


Table S6 Coefficients of linear mixed effects model analysing the fixed effects from mixture plant residues and day as well as their interaction on soil respiration rate $\left(\mu \mathrm{g} \mathrm{g} \mathrm{g}^{-1} \mathrm{~h}^{-1}\right)$, fungi to bacteria ratio, and the biomass ( $\mu \mathrm{g} \mathrm{C}^{-1}$ ) of total PLFA, fungi, Gram-positive bacteria, Gramnegative bacteria, eukaryote, protozoa, AM fungi, actinobacteria, cyanobacteria, and unknown microbial group. DF means degree of freedom. The effects are the effects of the quaternary mixture of cover crop residues with a comparison to the average of the four individuals. The respiration was compared at two time scales: over 84 days or from day 30 to 84 days. ${ }^{*}, * *, * * *$ indicates significant at $P<0.05,0.01$, and 0.001 .

\begin{tabular}{|c|c|c|c|c|c|c|c|c|}
\hline \multirow[t]{2}{*}{ Indicators } & \multicolumn{2}{|l|}{ Intercept } & \multicolumn{2}{|l|}{ Mix } & \multicolumn{2}{|l|}{ Day } & \multicolumn{2}{|l|}{ Mix*Day } \\
\hline & Effects & DF & Effects & DF & Effects & DF & Effects & $\mathrm{DF}$ \\
\hline Respiration (84 days) & $373.35^{* * *}$ & 358 & 2.87 & 18 & $-1.80 * * *$ & 358 & 0.42 & 358 \\
\hline Respiration ( 30 to 84 days) & $305.18^{* * *}$ & 138 & $57.61^{*}$ & 18 & $-0.78 * * *$ & 138 & -0.45 & 138 \\
\hline Total PLFA & $76.60 * * *$ & 38 & 2.05 & 18 & $-0.53 * * *$ & 38 & -0.06 & 38 \\
\hline Fungi to bacteria ratio & $0.83 * * *$ & 38 & 0.03 & 18 & $-0.005^{* * *}$ & 38 & -0.0004 & 38 \\
\hline Fungi & $32.41 * * *$ & 38 & 1.33 & 18 & $-0.30 * * *$ & 38 & -0.03 & 38 \\
\hline Gram-positive bacteria & $32.52 * * *$ & 38 & 0.69 & 18 & $-0.23 * * *$ & 38 & -0.03 & 38 \\
\hline Gram-negative bacteria & $6.49 * * *$ & 38 & -0.21 & 18 & 0.004 & 38 & 0.003 & 38 \\
\hline Eukaryote & $0.19 * * *$ & 38 & 0.004 & 18 & -0.0008 & 38 & 0.00003 & 38 \\
\hline Protozoa & $0.55^{* * *}$ & 38 & 0.18 & 18 & 0.0006 & 38 & -0.001 & 38 \\
\hline AM fungi & $0.97 * * *$ & 38 & 0.10 & 18 & $-0.003^{*}$ & 38 & -0.005 & 38 \\
\hline Actinobacteria & $1.87^{* * *}$ & 38 & 0.025 & 18 & $0.008^{*}$ & 38 & -0.005 & 38 \\
\hline Cyanobacteria & $0.18^{* * *}$ & 38 & -0.07 & 18 & $-0.001 * *$ & 38 & 0.0009 & 38 \\
\hline Unknown & $1.42 * * *$ & 38 & 0.008 & 18 & $-0.006 * * *$ & 38 & -0.0006 & 38 \\
\hline
\end{tabular}


Table S7 Pearson correlation of respiration and PLFA biomass in different group in 3 time points (day 1, 35, and 84). G+ and G- represent Gram-positive and Gram-negative bacteria, respectively. Sum represents total PLFA biomass. FB Ratio is fungi to bacteria ratio. $*, * *$, and $* * *$ represent significant correlation at $P<0.05,0.01$, and 0.001 .

\begin{tabular}{|c|c|c|c|c|c|c|c|c|c|c|c|c|}
\hline & $\mathrm{CO}_{2}$ & $\begin{array}{l}\text { Actinob } \\
\text { acteria }\end{array}$ & $\begin{array}{l}\text { Fun } \\
\mathrm{gi}\end{array}$ & $\mathrm{G}+$ & G- & $\begin{array}{l}\text { Cyanob } \\
\text { acteria }\end{array}$ & $\begin{array}{l}\text { AM } \\
\text { fungi }\end{array}$ & $\begin{array}{l}\text { Unkn } \\
\text { own }\end{array}$ & $\begin{array}{l}\text { Eukar } \\
\text { yote }\end{array}$ & $\begin{array}{l}\text { Prot } \\
\text { ozoa }\end{array}$ & Sum & $\begin{array}{l}\text { FB } \\
\text { Rati } \\
\text { o }\end{array}$ \\
\hline & & & 0.85 & 0.89 & 0.35 & & 0.27 & 0.62 & $0.33^{*}$ & & 0.89 & 0.84 \\
\hline $\mathrm{CO}_{2}$ & & 0.06 & $* * *$ & $* * *$ & $* *$ & $0.51 * * *$ & $*$ & $* * *$ & $*$ & 0.18 & $* * *$ & $* * *$ \\
\hline Actinob & & & - & & 0.71 & & 0.44 & 0.32 & & 0.44 & & - \\
\hline acteria & 0.06 & & 0.14 & 0.06 & $* * *$ & $0.29 *$ & $* * *$ & $* *$ & 0.18 & $* * *$ & 0.05 & 0.20 \\
\hline & 0.85 & & & 0.96 & & & 0.27 & 0.62 & $0.31 *$ & & 0.97 & 0.97 \\
\hline Fungi & $* * *$ & -0.14 & & $* * *$ & 0.13 & $0.46 * * *$ & $*$ & $* * *$ & $*$ & 0.06 & $* * *$ & $* * *$ \\
\hline & 0.89 & & 0.96 & & 0.33 & & 0.43 & 0.72 & $0.37^{*}$ & & 0.99 & 0.89 \\
\hline G+ & $* * *$ & 0.06 & $* * *$ & & $* *$ & $0.51^{* * *}$ & $* * *$ & $* * *$ & * & 0.17 & $* * *$ & $* * *$ \\
\hline & 0.35 & & & 0.33 & & & 0.44 & 0.55 & $0.38^{*}$ & 0.57 & 0.33 & \\
\hline G- & $* *$ & $0.71^{* * *}$ & 0.13 & $* *$ & & $0.45^{* * *}$ & $* * *$ & $* * *$ & $* *$ & $* * *$ & $* *$ & 0.00 \\
\hline $\begin{array}{l}\text { Cyanob } \\
\text { acteria }\end{array}$ & $\begin{array}{l}0.51 \\
* * *\end{array}$ & $0.29 *$ & $\begin{array}{l}0.46 \\
* * *\end{array}$ & $\begin{array}{l}0.51 \\
* * *\end{array}$ & $\begin{array}{l}0.45 \\
* * *\end{array}$ & & $\begin{array}{l}0.50 \\
* * *\end{array}$ & $\begin{array}{l}0.69 \\
* * *\end{array}$ & $\begin{array}{l}0.60 * \\
* *\end{array}$ & $\begin{array}{l}0.50 \\
* * *\end{array}$ & $\begin{array}{l}0.54 \\
* * *\end{array}$ & $\begin{array}{l}0.43 \\
* * *\end{array}$ \\
\hline AM & 0.27 & & 0.27 & 0.43 & 0.44 & & & 0.70 & $0.56^{*}$ & 0.46 & 0.42 & \\
\hline fungi & $*$ & $0.44^{* * *}$ & $*$ & $* * *$ & $* * *$ & $0.50 * * *$ & & $* * *$ & $* *$ & $* * *$ & $* * *$ & 0.19 \\
\hline Unkno & 0.62 & & 0.62 & 0.72 & 0.55 & & 0.70 & & $0.59 *$ & 0.43 & 0.73 & 0.51 \\
\hline wn & $* * *$ & $0.32 * *$ & $* * *$ & $* * *$ & $* * *$ & $0.69 * * *$ & $* * *$ & & $* *$ & $* * *$ & $* * *$ & $* * *$ \\
\hline Eukaryo & 0.33 & & 0.31 & 0.37 & 0.38 & & 0.56 & 0.59 & & 0.83 & 0.40 & 0.26 \\
\hline te & $* *$ & 0.18 & $* *$ & $* *$ & $* * *$ & $0.60 * * *$ & $* * *$ & $* * *$ & & $* * *$ & $* * *$ & $*$ \\
\hline Protozo & & & & & 0.57 & & 0.46 & 0.43 & $0.83 *$ & & & \\
\hline $\mathrm{a}$ & 0.18 & $0.44^{* * *}$ & 0.06 & 0.17 & $* * *$ & $0.50 * * *$ & $* * *$ & $* * *$ & $* *$ & & 0.20 & 0.00 \\
\hline & 0.89 & & 0.97 & 0.99 & 0.33 & & 0.42 & 0.73 & $0.40^{*}$ & & & 0.91 \\
\hline Sum & $* * *$ & 0.05 & $* * *$ & $* * *$ & $* *$ & $0.54 * * *$ & $* * *$ & $* * *$ & $* *$ & 0.20 & & $* * *$ \\
\hline FB & 0.84 & & 0.97 & 0.89 & & & & 0.51 & & & 0.91 & \\
\hline Ratio & $* * *$ & -0.20 & $* * *$ & $* * *$ & 0.00 & $0.43^{* * *}$ & 0.19 & $* * *$ & $0.26^{*}$ & 0.00 & $* * *$ & \\
\hline
\end{tabular}

5 